\title{
Editorial
}

Theme: Celebrating Women in the Pharmaceutical Sciences

Guest Editors: Diane Burgess, Marilyn Morris and Meena Subramanyam

\section{Women in the Pharmaceutical Sciences: Honoring Our Pioneers}

\author{
Amy Lavelle ${ }^{1}$ and Marilyn E. Morris ${ }^{2,3}$ (D)
}

Received 5 October 2020; accepted 9 October 2020; published online 23 October 2020

The AAPS $J$ theme issue "Celebrating Women in the Pharmaceutical Sciences" recognizes the contributions women have made to science in the broad research area included in the term "pharmaceutical sciences." Similar to most scientific areas, it has been a slow process for women reaching the upper echelons of the pharmaceutical world in industry or academia.

Historically, a number of women have achieved distinction. A few that have greatly impacted our science in the pharmaceutical and biotech industry and academia are included here.

Marie Curie (1867-1934) was a Polish mathematician and pioneering chemist who developed the theory of radioactivity and discovered two chemical elements of the periodic table, polonium and radium. She also invented "Petites Curies," mobile x-ray units for use in field hospitals during World War I. Curie was the recipient of the Nobel Prize in Physics in 1904 and a second Nobel Prize in Chemistry in 1911, the only woman in history who has been awarded two Nobel Prizes. The Curie Institute that she founded in 1920 remains a major cancer research institute in Paris (https://www.wikipedia.org/, https://www.discovermagazine.com/the-sciences/meet-10women-in-science-who-changed-the-world, https:// www.proclinical.com/blogs/2020-3/10-most-influential-womenin-history-of-science-and-medicine).

Margaret Oakley Dayhoff (1925-1983) was an American physical chemist, research biochemist, and is known as one of the most influential scientists in the development of bioinformatics. She joined the National Biomedical Research Foundation in 1959. She is best known for her innovative method of sequencing of proteins and nucleic acids through the application of mathematics and computational techniques. In

Guest Editors: Diane Burgess, Marilyn Morris and Meena Subramanyam

\footnotetext{
${ }^{1}$ Manager Labs, Immunochemistry R\&D, PPD Laboratories ${ }^{\circledR}, 2244$ Dabney Rd, Richmond, VA 23230-3323, USA.

${ }^{2}$ Department of Pharmaceutical Sciences, School of Pharmacy and Pharmaceutical Sciences, University at Buffalo, State University of New York, Buffalo, NY 14214-8033, USA.

${ }^{3}$ To whom correspondence should be addressed. (e-mail: memorris@buffalo.edu)
}

1965, she published the Atlas of Protein Sequence and Structure which reported all known protein sequences. This eventually led to establishment of the first publicly available database for protein sequences: The Protein Information Resource (https://www.wikipedia.org/).

Gertrude "Trudy" Elion (1918-1999) was an American biochemist and pharmacologist who started as a food quality supervisor for A\&P Supermarkets before moving to Johnson and Johnson testing suture strength. In 1944, she joined Burroughs-Wellcome (now GSK) as a researcher, working in drug development where she developed the anti-cancer drugs tioguanine and mercaptopurine. She, with her team, was the developer of 45 patents including new drugs to treat leukemia, AIDS, malaria, gout, herpes, and organ rejection. She was the recipient of the 1988 Nobel Prize in Physiology or Medicine, along with George H. Hitchins and Sir James Black for the development of innovative techniques for drug development known as rational drug design targeting the biochemical and metabolic differences between normal human cells and pathogens (https://www.wikipedia.org/, https://www.proclinical.com/blogs/2020-3/10-most-influentialwomen-in-history-of-science-and-medicine).

Rosalyn Yalow (1921-2011) was a medical physicist and the first American woman to win the Nobel Prize in Physiology or Medicine for the development of the radioimmunoassay, along with Roger Guillemin and Andrew Schally. Thinking graduate schools would not fund a woman, she started as a secretary then went on to be a teaching assistant and eventually worked at the Bronx VA Hospital in the radioisotope laboratory, developing the radioimmunoassay for accurate hormone measurement. She has received numerous awards including the National Medal of Science and induction to the National Women's Hall of Fame. While she was not a champion of recognizing women in the sciences, as she felt women and men should be regarded equally, many look up to her for her important contributions (https:// www.wikipedia.org/).

Brigitte Askonas (1923-2013) was known as the "Grand Dame" of Immunology. She studied biochemistry under mentors Marjory Stephenson and Dorothy Needham who taught her "good science gets recognition regardless of the sex of the scientist." She spent her career at the National 
Institute for Medical Research in the UK. There she codeveloped one of the first methods for cloning antibodyforming B cells as well as developed a method to isolate and clone virus specific T lymphocytes. She studied their role in infections, particularly defining different influenza sub-sets, disease pathogenesis, and contributing to modern vaccine development. She was elected Fellow of the Academy of Medical Sciences in 2007 as an international member and received the Robert Koch Gold Medal (https:// www.wikipedia.org/, https:/www.whatisbiotechnology.org/ index.php/people/summary/Askonas).

Frances Oldham Kelsey (1914-2015) was a Canadianborn American pharmacologist and physician. In 1960, as a newly appointed reviewer at the US Food and Drug Administration, her first assignment was reviewing thalidomide as a tranquilizer, painkiller, and for use in morning sickness. She withheld approval and requested data showing the drug was not harmful to the fetus, due to the lack of clinical evidence to support the drug's safety claims, as well as evidence of birth defects. Ultimately, she refused to approve the drug, preventing numerous physical deformities of infants. Her persistence helped shaped FDA's drug approval regulations passed in 1962. Kelsey was appointed deputy for scientific and medical affairs for FDA's CDER in 1995 and in her time there, influenced the agency's testing and review processes and implemented measures to protect patients involved in drug investigations (https://www.wikipedia.org/).

Tu Youyou (1930-) is a pharmaceutical chemist best known for her research on malaria. She is credited with saving millions of lives through her discovery of artemisinin and dihydroartemisinin for the treatment of malaria and received the Nobel Prize in Physiology or Medicine for her work (with William C. Campbell and Satoshi Omura). She discovered the compound, extracted from sweet wormwood, in a 1600-year-old text, volunteered to be the first human subject and published her clinical trial results anonymously. Before winning the Nobel Prize, she was "almost completely forgotten by people" (https://www.wikipedia.org/).

In celebrating the scientific accomplishments of women in the pharmaceutical sciences, it is important to continue to recognize and acknowledge women in the field. The American Association of Pharmaceutical Scientists (AAPS) salary survey from 2019 indicated that currently women make up
$38 \%$ of members. In addition to membership numbers, women have lagged in awards; for example, the highest scientific award in AAPS, the Distinguished Pharmaceutical Scientist Award, has never been awarded to a woman. This year, AAPS Past-President Alice Till initiated a new award, the Alice E. Till Advancement of Women in Pharmaceutical Sciences Recognition Award. Despite the smaller number of women members in AAPS, there have been several women presidents including Binodh DeSilva (2017), Alice E. Till (2015), Marilyn Morris (2014), Karen Habucky (2008), Diane Burgess (2002), and Marilyn Dix Smith (1991). Additionally, the incoming president-elect for 2021 is Annette Bak, who herself has been very active in recognizing women in science throughout her career in her work at AAPS and beyond. There is also a very active Women in Pharmaceutical Science community (WIPS), introduced in 2019, supporting mentorship and career development programs for women. In an effort to address issues surrounding underrepresented minorities, AAPS surveyed members in June, focusing on diversity and inclusion, and will be releasing their findings and resulting initiatives this fall (www.aaps.org).

On behalf of the guest editors of this theme issue, Diane Burgess, Marilyn Morris, and Meena Subramanyam, we thank all the women scientists who enthusiastically submitted a scientific manuscript for this theme issue. History has shown us that the achievements and contributions of women are fundamentally important to our field. We strive to continue to recognize those women.

\section{ACKNOWLEDGMENTS}

We thank Tianjing Ren for assistance with the graphical abstract.

After submission of this editorial, the Norwegian Nobel Prize Committee announced that two women scientists, American biochemist Jennifer A. Doudna and the French microbiologist Emmanuelle Charpentier, were awarded the 2020 Nobel Prize in Chemistry for their contributions to gene editing with Crispr/cas9. It is the first time two women have won a science Nobel Prize together, and we congratulate these women on this prestigious award and for their contributions to science.

Publisher's Note Springer Nature remains neutral with regard to jurisdictional claims in published maps and institutional affiliations. 